GISLAINE DOS SANTOS SILVA

\title{
EFEITO DE SESSÃO REPETIDA DE EXERCÍCIO EXCÊNTRICO NA EXPRESSÃO DE GENES PRÓ E ANTI-INFLAMATÓRIOS NO MÚSCULO ESQUELÉTICO
}

Dissertação apresentada ao Programa de Pós-Graduação em Ciências Morfofuncionais do Instituto de Ciências Biomédicas da Universidade de São Paulo, para obtenção do Título de Mestre em Ciências.

Área de Concentração: Ciências Morfofuncionais

Orientadora: $\operatorname{Prof}^{\underline{a}} \operatorname{Dr}^{\underline{a}}$ Elen Haruka Miyabara

Versão corrigida. A versão original eletrônica encontra-se disponível tanto na Biblioteca do ICB quanto na Biblioteca Digital de Teses e Dissertações da USP (BDTD). 


\section{RESUMO}

Silva GS. Efeito de sessão repetida de exercício excêntrico na expressão de genes pró e anti-inflamatórios no músculo esquelético. [Dissertação (Mestrado em Ciências Morfofuncionais)] São Paulo: Instituto de Ciências Biomédicas, Universidade de São Paulo; 2015.

Diante da importância da integridade muscular para a manutenção da qualidade de vida e para a prática de atividade física, torna-se cada vez maior o interesse na investigação de estratégias capazes de maximizar a resposta regenerativa muscular. Neste contexto, o estudo do possível efeito "protetor" gerado por sessão repetida de exercício excêntrico na musculatura esquelética ainda é pouco explorado. As contrações excêntricas causam lesão muscular por meio do desarranjo dos filamentos dos sarcômeros, o que leva à ruptura do sarcolema, aumento da concentração de $\mathrm{Ca}^{+2}$ intracelular com subsequente ativação de proteólise. Por outro lado, uma sessão repetida de exercício excêntrico acarreta na redução da lesão muscular com consequente atenuação da dor e da perda de força muscular. Esse fenômeno, uma espécie de mecanismo protetor, é conhecido como "efeito da carga repetida". Visando contribuir para o melhor entendimento do efeito da carga repetida sobre a musculatura esquelética, em especial, a expressão de genes pró e antiinflamatórios após o dano promovido pelo exercício excêntrico, camundongos selvagens foram submetidos a uma ou duas sessões de exercício excêntrico e os músculos sóleos foram avaliados após 24 horas e 3 dias. A análise histológica mostrou fibras musculares lesadas nos músculos sóleos de animais submetidos à $1^{\underline{a}}$ sessão, com considerável atenuação no número de fibras musculares lesadas nos animais submetidos à $2^{\underline{a}}$ sessão. Em geral, a expressão gênica das citocinas próinflamatórias (TNF- $\alpha$, iNOS e IL-1 $\beta$ ) e anti-inflamatórias (IL-10, YM1, Fizz-1 e Arginase-1) foi alta em $24 \mathrm{~h}$ após a $1^{\underline{a}}$ sessão, e reduziu aos níveis do grupo controle em $24 \mathrm{~h}$ após a $2^{\mathrm{a}}$ sessão de exercício excêntrico. Nossos resultados sugerem que o aumento da expressão gênica dessas citocinas pró e anti-inflamatórias no tecido muscular antes da $2^{\underline{a}}$ sessão pode ter contribuído para a atenuação da lesão muscular detectada em $24 \mathrm{~h}$ após a $2^{\mathrm{a}}$ sessão de exercício excêntrico.

Palavras-chave: Músculo esquelético. Citocinas inflamatórias. Exercício excêntrico. Efeito da carga repetida. Expressão gênica. 


\begin{abstract}
Silva GS. Repeated session effect of eccentric exercise in expression of pro and antiinflammatory genes in skeletal muscle. [Masters thesis (Morphofunctional Science)] São Paulo: Instituto de Ciências Biomédicas, Universidade de São Paulo; 2015.

Considering that muscle integrity is crucial for maintenance of quality of life and for physical activity, there is an increasing interest in the investigation of strategies able to maximize the muscle regenerative process. In this context, the study of the possible protective effect generated by repeated eccentric exercise bout on skeletal muscle is still poorly explored. The eccentric contractions cause muscle injury through the disarray of sarcomere filaments, which leads to sarcolemma disruption, increase in the intracellular calcium concentration with subsequent activation of proteolysis. Moreover, one repeated eccentric exercise bout cause attenuation of muscle damage and consequent pain relief and loss of muscle strength. This phenomenon, a protective mechanism, is known as "repeated bout effect". In order to contribute to a better understanding of the repeated bout effect on skeletal muscle, in particular, the expression of pro and anti-inflammatory genes after injury caused by eccentric exercise, wild-type mice were subjected to one or two bouts of eccentric exercise and soleus muscles were evaluated after 24 hours or 3 days. Histological analysis showed damaged myofibers in soleus muscles from animals subjected to the $1^{\text {st }}$ bout, with considerable attenuation in the number of injured myofibers from animals subjected to the $2^{\text {nd }}$ bout. In general, the gene expression of proinflammatory (TNF- $\alpha$, iNOS and IL-1 $\beta$ ) and anti-inflammatory (IL-10, YM1, Fizz-1 and Arginase-1) cytokines was high at $24 \mathrm{~h}$ post the $1^{\text {st }}$ bout, and reduced to the control group levels at $24 \mathrm{~h}$ after two bouts of eccentric exercise. Our results suggest that the increased gene expression of these pro and anti-inflammatory cytokines in muscle tissue before the $2^{\text {nd }}$ bout might contribute to the attenuation of muscle injury detected in $24 \mathrm{~h}$ after the $2^{\text {nd }}$ bout of eccentric exercise.
\end{abstract}

Keywords: Skeletal muscle. Inflammatory cytokines. Eccentric exercise. Repeated bout effect. Gene expression. 


\section{INTRODUÇÃO}

\subsection{Características gerais do músculo esquelético}

O músculo esquelético é inervado e vascularizado, representando em torno de 50\% da massa do corpo humano (Karagounis, Hawley, 2010; Yusuf, BrandSaberi, 2012). Composto por fibras musculares e tecido conjuntivo (epimísio, perimísio e endomísio), o músculo esquelético atua como um arcabouço de sustentação do esqueleto, permitindo a movimentação coordenada do corpo (Bassel-Duby, Olson, 2006; Keynes, Aidley, 2001; Powers, Howley, 2005). Além disso, o músculo esquelético participa do metabolismo servindo de reserva de substratos (por exemplo, glicogênio e proteína) e auxilia na homeostase da temperatura corpórea (Donati et al., 2013; Zanou, Gailly, 2013).

Cada fibra muscular contém diversos núcleos periféricos e miofibrilas que são estruturas alongadas compostas por sarcômeros, unidades funcionais contráteis do músculo esquelético (Junqueira, Carneiro, 2008; Keynes, Aidley, 2001; Lieber, 2002; Tajsharghi, 2008). Os sarcômeros são constituídos principalmente por filamentos de actina e miosina (Clark et al., 2002; Maclntosh et al., 2006), os quais sobrepostos garantem o padrão estriado ao longo da fibra muscular esquelética.

Além das características mencionadas, a musculatura esquelética apresenta alta plasticidade frente à ausência ou à presença de estímulos (Harridge, 2007; Karagounis, Hawley, 2010; Pette, 2001), podendo atrofiar (Jackman, Kandarian, 2004), hipertrofiar (D'Antona et al., 2006; Zanou, Gailly, 2013), promover a conversão de tipos de fibras musculares (Tiidus, 2008) ou se regenerar após uma lesão (Jarvinen et al., 2005; Quintana et al., 2015). Dentre os possíveis estímulos lesivos como, por exemplo, a exposição à cardiotoxina (CTX) (Liu et al., 2014), ao cloreto de bário (Hong et al., 2012), à queimadura (Diaz et al., 2015) e às lacerações (Jarvinen et al., 2005), decidimos focar no estresse mecânico promovido pelo exercício excêntrico (Armstrong et al., 1983; Touchberry et al., 2012). 


\section{CONCLUSÃO}

Considerando que as citocinas pró e anti-inflamatórias possuem importantes funções na resposta imune e recuperação de tecidos lesados, nossos resultados sugerem que a elevação dos níveis de expressão gênica de citocinas pró e antiinflamatórias contribuiu para a atenuação da lesão muscular detectada após a repetição de uma sessão de exercício excêntrico. 


\section{REFERÊNCIAS*}

Acharyya S, Villalta SA, Bakkar N, Bupha-Intr T, Janssen PM, Carathers M, Li ZW, Beg AA, Ghosh S, Sahenk Z, Weinstein M, Gardner KL, Rafael-Fortney JA, Karin M, Tidball JG, Baldwin AS, Guttridge DC. Interplay of IKK/NF-kappaB signaling in macrophages and myofibers promotes muscle degeneration in Duchenne muscular dystrophy. J Clin Invest. 2007 Apr;117(4):889-901.

Allen DG. Eccentric muscle damage: mechanisms of early reduction of force. Acta Physiol Scand. 2001 Mar;171(3):311-9.

Armstrong RB, Ogilvie RW, Schwane JA. Eccentric exercise-induced injury to rat skeletal muscle. J Appl Physiol Respir Environ Exerc Physiol. 1983 Jan;54(1):80-93.

Armstrong RB, Taylor CR. Glycogen loss in rat muscles during locomotion on different inclines. J Exp Biol. 1993 Mar;176:135-44.

Arnold L, Henry A, Poron F, Baba-Amer Y, van Rooijen N, Plonquet A, Gherardi RK, Chazaud B. Inflammatory monocytes recruited after skeletal muscle injury switch into antiinflammatory macrophages to support myogenesis. J Exp Med. 2007 May 14;204(5):1057-69.

Balnave CD, Davey DF, Allen DG. Distribution of sarcomere length and intracellular calcium in mouse skeletal muscle following stretch-induced injury. J Physiol. 1997 Aug 1;502 ( Pt 3):649-59.

Barash IA, Peters D, Friden J, Lutz GJ, Lieber RL. Desmin cytoskeletal modifications after a bout of eccentric exercise in the rat. Am J Physiol Regul Integr Comp Physiol. 2002 Oct;283(4):R958-63.

Barroso R, Tricoli V, Ugrinowitsch C. Adaptações neurais e morfológicas ao treinamento de força com ações excêntricas. R bras Ci e Mov. 2005 Mar;13(2):11122.

Bassel-Duby R, Olson EN. Signaling pathways in skeletal muscle remodeling. Annu Rev Biochem. 2006;75:19-37.

Brockett CL, Morgan DL, Proske U. Human hamstring muscles adapt to eccentric exercise by changing optimum length. Med Sci Sports Exerc. 2001 May;33(5):78390.

Brown SJ, Child RB, Day SH, Donnelly AE. Exercise-induced skeletal muscle damage and adaptation following repeated bouts of eccentric muscle contractions. J Sports Sci. 1997 Apr;15(2):215-22.

${ }^{*}$ De acordo com:

International Committee of Medical Journal Editors. [Internet].Uniform requirements for manuscripts submitted to biomedical journals. [2011 Jul 15]. Available from: htpp://www.nlm.nih.gov/bsd/uniform_requirements.html. 
Buford TW, Cooke MB, Shelmadine BD, Hudson GM, Redd L, Willoughby DS. Effects of eccentric treadmill exercise on inflammatory gene expression in human skeletal muscle. Appl Physiol Nutr Metab. 2009 Aug;34(4):745-53.

Burdzinska A, Gala K, Kowalewski C, Zagozdzon R, Gajewski Z, Paczek L. Dynamics of Acute Local Inflammatory Response after Autologous Transplantation of Muscle-Derived Cells into the Skeletal Muscle. Mediat Inflamm. 2014.

Chavanelle V, Sirvent P, Ennequin G, Caillaud K, Montaurier C, Morio B, Boisseau $\mathrm{N}$, Richard R. Comparison of oxygen consumption in rats during uphill (concentric) and downhill (eccentric) treadmill exercise tests. J Sports Sci Med. 2014 Sep;13(3):689-94.

Chen TCC, Chen HL, Pearce AJ, Nosaka K. Attenuation of Eccentric ExerciseInduced Muscle Damage by Preconditioning Exercises. Med Sci Sport Exer. 2012 Nov;44(11):2090-8.

Ciciliot S, Schiaffino S. Regeneration of Mammalian Skeletal Muscle: Basic Mechanisms and Clinical Implications. Curr Pharm Design. 2010 Mar;16(8):906-14.

Clark KA, McElhinny AS, Beckerle MC, Gregorio CC. Striated muscle cytoarchitecture: An intricate web of form and function. Annu Rev Cell Dev Bi. 2002;18:637-706.

Clarkson PM, Tremblay I. Exercise-Induced Muscle Damage, Repair, and Adaptation in Humans. J Appl Physiol. 1988 Jul;65(1):1-6.

Cooper ST, Head SI. Membrane Injury and Repair in the Muscular Dystrophies. Neuroscientist. 2014 Nov 18.

D'Antona G, Lanfranconi F, Pellegrino MA, Brocca L, Adami R, Rossi R, Moro G, Miotti D, Canepari M, Bottinelli R. Skeletal muscle hypertrophy and structure and function of skeletal muscle fibres in male body builders. J Physiol. 2006 Feb 1;570(Pt 3):611-27.

Dasgupta P, Chapoval SP, Smith EP, Keegan AD. Transfer of in vivo primed transgenic $T$ cells supports allergic lung inflammation and FIZZ1 and Ym1 production in an IL-4Ralpha and STAT6 dependent manner. BMC Immunol. 2011;12:60.

Dedkov El, Borisov AB, Wernig A, Carlson BM. Aging of skeletal muscle does not affect the response of satellite cells to denervation. J Histochem Cytochem. 2003 Jul;51(7):853-63.

Diaz EC, Herndon DN, Porter C, Sidossis LS, Suman OE, Borsheim E. Effects of pharmacological interventions on muscle protein synthesis and breakdown in recovery from burns. Burns. 2015 Jun;41(4):649-57.

Donati C, Cencetti F, Bruni P. Sphingosine 1-phosphate axis: a new leader actor in skeletal muscle biology. Front Physiol. 2013;4. 
Edman KA. Contractile properties of mouse single muscle fibers, a comparison with amphibian muscle fibers. J Exp Biol. 2005 May;208(Pt 10):1905-13.

Enoka RM. Eccentric contractions require unique activation strategies by the nervous system. J Appl Physiol. 1996 Dec;81(6):2339-46.

Enoka RM. Neuromechanics of human movement. Champaign, IL: Human Kinetics; 2002. $556 \mathrm{p}$.

Ghosh S, Hayden MS. New regulators of NF-kappaB in inflammation. Nat Rev Immunol. 2008 Nov;8(11):837-48.

Grefte S, Kuijpers-Jagtman AM, Torensma R, Von den Hoff JW. Skeletal muscle development and regeneration. Stem Cells Dev. 2007 Oct;16(5):857-68.

Hamada K, Vannier E, Sacheck JM, Witsell AL, Roubenoff R. Senescence of human skeletal muscle impairs the local inflammatory cytokine response to acute eccentric exercise FASEB J 2005 Feb;19(2):264-6.

Hamer PW, McGeachie JM, Davies MJ, Grounds MD. Evans Blue Dye as an in vivo marker of myofibre damage: optimising parameters for detecting initial myofibre membrane permeability. J Anat. 2002 Jan;200(1):69-79.

Haramizu S, Ota N, Hase T, Murase T. Catechins attenuate eccentric exerciseinduced inflammation and loss of force production in muscle in senescenceaccelerated mice. J Appl Physiol (1985). 2011 Dec;111(6):1654-63.

Harridge SD. Plasticity of human skeletal muscle: gene expression to in vivo function. Exp Physiol. 2007 Sep;92(5):783-97.

Hody S, Lacrosse Z, Leprince P, Collodoro M, Croisier JL, Rogister B. Effects of eccentrically and concentrically biased training on mouse muscle phenotype. Med Sci Sports Exerc. 2013 Aug;45(8):1460-8.

Holcomb IN, Kabakoff RC, Chan B, Baker TW, Gurney A, Henzel W, Nelson C, Lowman HB, Wright BD, Skelton NJ, Frantz GD, Tumas DB, Peale FV, Jr., Shelton DL, Hebert CC. FIZZ1, a novel cysteine-rich secreted protein associated with pulmonary inflammation, defines a new gene family. EMBO J. 2000 Aug 1;19(15):4046-55.

Hollander J, Fiebig R, Gore M, Ookawara T, Ohno H, Ji LL. Superoxide dismutase gene expression is activated by a single bout of exercise in rat skeletal muscle. Pflug Arch Eur J Phy. 2001 Jun;442(3):426-34.

Hong P, Chen K, Huang BH, Liu M, Cui M, Rozenberg I, Chaqour B, Pan XY, Barton $E R$, Jiang XC, Siddiqui MAQ. HEXIM1 controls satellite cell expansion after injury to regulate skeletal muscle regeneration. Journal of Clinical Investigation. 2012 Nov;122(11):3873-87. 
Howell JN, Chila AG, Ford G, David D, Gates T. An Electromyographic Study of Elbow Motion during Postexercise Muscle Soreness. J Appl Physiol. 1985;58(5):1713-8.

Hubal MJ, Chen TC, Thompson PD, Clarkson PM. Inflammatory gene changes associated with the repeated-bout effect. Am J Physiol-Reg I. 2008 May;294(5):R1628-R37.

Ichikawa T, Li JQ, Nagarkatti P, Nagarkatti M, Hofseth LJ, Windust A, Cui TX. American ginseng preferentially suppresses STAT/iNOS signaling in activated macrophages. J Ethnopharmacol. 2009 Aug 17;125(1):145-50.

Isanejad A, Saraf ZH, Mahdavi M, Gharakhanlou R, Shamsi MM, Paulsen G. The effect of endurance training and downhill running on the expression of IL-1beta, IL-6, and TNF-alpha and HSP72 in rat skeletal muscle. Cytokine. 2015 Jun;73(2):302-8.

Jackman RW, Kandarian SC. The molecular basis of skeletal muscle atrophy. Am J Physiol Cell Physiol. 2004 Oct;287(4):C834-43.

Jarvinen TA, Jarvinen TL, Kaariainen $M$, Kalimo $H$, Jarvinen $M$. Muscle injuries: biology and treatment. Am J Sports Med. 2005 May;33(5):745-64.

Junqueira LCU, Carneiro J. Histologia Básica. 11. ed. Rio de Janeiro: Guanabara Koogan; 2008. 556 p.

Kamandulis S, Skurvydas A, Brazaitis M, Skikas L, Duchateau J. The repeated bout effect of eccentric exercise is not associated with changes in voluntary activation. Eur J Appl Physiol. 2010 Apr;108(6):1065-74.

Kanda K, Sugama K, Hayashida H, Sakuma J, Kawakami Y, Miura S, Yoshioka H, Mori Y, Suzuki K. Eccentric exercise-induced delayed-onset muscle soreness and changes in markers of muscle damage and inflammation. Exerc Immunol Rev. 2013;19:72-85.

Karagounis LG, Hawley JA. Skeletal muscle: increasing the size of the locomotor cell. Int J Biochem Cell Biol. 2010 Sep;42(9):1376-9.

Kawanishi N, Kato K, Takahashi M, Mizokami T, Otsuka Y, Imaizumi A, Shiva D, Yano $\mathrm{H}$, Suzuki K. Curcumin attenuates oxidative stress following downhill runninginduced muscle damage. Biochem Bioph Res Co. 2013 Nov 22;441(3):573-8.

Keynes RD, Aidley DJ. Nerve and muscle. 3. ed. Cambridge: Cambridge University Press; 2001. 179 p.

Kharraz Y, Guerra J, Mann CJ, Serrano AL, Munoz-Canoves P. Macrophage plasticity and the role of inflammation in skeletal muscle repair. Mediators Inflamm. 2013;2013:491497. 
Lapointe $\mathrm{BM}$, Fremont $\mathrm{P}$, Cote $\mathrm{CH}$. Adaptation to lengthening contractions is independent of voluntary muscle recruitment but relies on inflammation. Am $\mathrm{J}$ Physiol-Reg I. 2002 Jan;282(1):R323-R9.

Lehti TM, Kalliokoski R, Komulainen J. Repeated bout effect on the cytoskeletal proteins titin, desmin, and dystrophin in rat skeletal muscle. J Muscle Res Cell Motil. 2007;28(1):39-47.

Liao P, Zhou J, Ji LL, Zhang Y. Eccentric contraction induces inflammatory responses in rat skeletal muscle: role of tumor necrosis factor-alpha. Am J Physiol Regul Integr Comp Physiol. 2010 Mar;298(3):R599-607.

Lieber RL. Skeletal muscle structure, function \& plasticity : the physiological basis of rehabilitation. Baltimore: Lippincott Williams \& Wilkins. 2002. [300 p.].

Liu N, Nelson BR, Bezprozvannaya S, Shelton JM, Richardson JA, Bassel-Duby R, Olson EN. Requirement of MEF2A, C, and D for skeletal muscle regeneration. Proc Natl Acad Sci U S A. 2014 Mar 18;111(11):4109-14.

Lynn R, Talbot JA, Morgan DL. Differences in rat skeletal muscles after incline and decline running. J Appl Physiol (1985). 1998 Jul;85(1):98-104.

MacKenzie KF, Pattison MJ, Arthur JS. Transcriptional regulation of IL-10 and its cellspecific role in vivo. Crit Rev Immunol. 2014;34(4):315-45.

Maclntosh BR, Gardiner PF, McComas AJ. Skeletal muscle: form and function. 2. ed. Champaign, IL: Human Kinetics; 2006. 423 p.

Mandal P, Pratt BT, Barnes M, McMullen MR, Nagy LE. Molecular mechanism for adiponectin-dependent M2 macrophage polarization: link between the metabolic and innate immune activity of full-length adiponectin. J Biol Chem. $2011 \mathrm{Apr}$ $15 ; 286(15): 13460-9$.

Mantovani A, Sica A, Sozzani S, Allavena P, Vecchi A, Locati M. The chemokine system in diverse forms of macrophage activation and polarization. Trends Immunol. 2004 Dec;25(12):677-86.

Margaria R. Positive and negative work performances and their efficiencies in human locomotion. Int Z Angew Physiol. 1968 May 28;25(4):339-51.

Martinez CO, McHale MJ, Wells JT, Ochoa O, Michalek JE, McManus LM, Shireman PK. Regulation of skeletal muscle regeneration by CCR2-activating chemokines is directly related to macrophage recruitment. Am J Physiol-Reg I. 2010 Sep;299(3):R832-R42.

Martinez FO, Sica A, Mantovani A, Locati M. Macrophage activation and polarization. Front Biosci-Landmrk. 2008 Jan 1;13:453-61.

Martini FH, Timmons MJ, Tallitsch RB. Anatomia humana. 6. ed. Porto Alegre: Artmed; 2009. 870 p. 
Maruhashi Y, Kitaoka K, Yoshiki Y, Nakamura R, Okano A, Nakamura K, Tsuyama T, Shima Y, Tomita K. ROS scavenging activity and muscle damage prevention in eccentric exercise in rats. J Physiol Sci. 2007 Aug;57(4):211-6.

McHugh MP. Recent advances in the understanding of the repeated bout effect: the protective effect against muscle damage from a single bout of eccentric exercise. Scand J Med Sci Sports. 2003 Apr;13(2):88-97.

McHugh MP, Connolly DA, Eston RG, Kremenic IJ, Nicholas SJ, Gleim GW. The role of passive muscle stiffness in symptoms of exercise-induced muscle damage. Am J Sports Med. 1999 Sep-Oct;27(5):594-9.

McHugh MP, Connolly DAJ, Eston RG, Gartman EJ, Gleim GW. Electromyographic analysis of repeated bouts of eccentric exercise. J Sport Sci. 2001 Mar;19(3):163-70.

Minari ALA, Oyama LM, dos Santos RVT. Downhill Exercise-Induced Changes in Gene Expression Related with Macrophage Polarization and Myogenic Cells in the Triceps Long Head of Rats. Inflammation. 2015 Feb;38(1):209-17.

Miyabara EH, Baptista IL, Lomonte B, Selistre-de-Araujo HS, Gutierrez JM, Moriscot AS. Effect of calcineurin inhibitors on myotoxic activity of crotoxin and Bothrops asper phospholipase A2 myotoxins in vivo and in vitro. Comp Biochem Physiol C Toxicol Pharmacol. 2006 Jul;143(3):284-94.

Moore LB, Sawyer AJ, Charokopos A, Skokos EA, Kyriakides TR. Loss of monocyte chemoattractant protein-1 alters macrophage polarization and reduces NFkappaB activation in the foreign body response. Acta Biomater. 2015 Jan;11:37-47.

Morgan DL. New Insights into the Behavior of Muscle during Active Lengthening. Biophys J. 1990 Feb;57(2):209-21.

Morgan DL, Allen DG. Early events in stretch-induced muscle damage. J Appl Physiol. 1999 Dec;87(6):2007-15.

Nair MG, Cochrane DW, Allen JE. Macrophages in chronic type 2 inflammation have a novel phenotype characterized by the abundant expression of Ym1 and Fizz1 that can be partly replicated in vitro. Immunol Lett. 2003 Jan 22;85(2):173-80.

Neumann DA. Cinesiologia do aparelho musculoesquelético: fundamentos para reabilitação. 2. ed. Rio de Janeiro: Elsevier; 2011.743 p.

Newham DJ, McPhail G, Mills KR, Edwards RH. Ultrastructural changes after concentric and eccentric contractions of human muscle. J Neurol Sci. 1983 Sep;61(1):109-22.

Nosaka K, Clarkson PM. Muscle damage following repeated bouts of high force eccentric exercise. Med Sci Sports Exerc. 1995 Sep;27(9):1263-9.

Nosaka K, Newton M. Concentric or eccentric training effect on eccentric exerciseinduced muscle damage. Med Sci Sports Exerc. 2002a Jan;34(1):63-9. 
Nosaka K, Newton M. Repeated eccentric exercise bouts do not exacerbate muscle damage and repair. J Strength Cond Res. 2002b Feb;16(1):117-22.

Nosaka K, Sakamoto K. Effect of elbow joint angle on the magnitude of muscle damage to the elbow flexors. Med Sci Sports Exerc. 2001 Jan;33(1):22-9.

Nosaka K, Sakamoto K, Newton M, Sacco P. How long does the protective effect on eccentric exercise-induced muscle damage last? Med Sci Sports Exerc. 2001 Sep;33(9):1490-5.

Ochi E, Nakazato K, Ishii N. Muscular hypertrophy and changes in cytokine production after eccentric training in the rat skeletal muscle. J Strength Cond Res. 2011 Aug;25(8):2283-92.

Ogilvie RW, Armstrong RB, Baird KE, Bottoms CL. Lesions in the rat soleus muscle following eccentrically biased exercise. Am J Anat. 1988 Aug;182(4):335-46.

Palladino MA, Bahjat FR, Theodorakis EA, Moldawer LL. Anti-TNF-alpha therapies: the next generation. Nat Rev Drug Discov. 2003 Sep;2(9):736-46.

Park KS, Lee MG. Effects of unaccustomed downhill running on muscle damage, oxidative stress, and leukocyte apoptosis. J Exerc Nutrition Biochem. 2015 Jun;19(2):55-63.

Paulsen G, Lauritzen F, Bayer ML, Kalhovde JM, Ugelstad I, Owe SG, Hallen J, Bergersen LH, Raastad T. Subcellular movement and expression of HSP27, alphaBcrystallin, and HSP70 after two bouts of eccentric exercise in humans. J Appl Physiol (1985). 2009 Aug;107(2):570-82.

Penas F, Mirkin GA, Vera M, Cevey A, Gonzalez CD, Gomez MI, Sales ME, Goren NB. Treatment in vitro with PPARalpha and PPARgamma ligands drives M1-to-M2 polarization of macrophages from T. cruzi-infected mice. Biochim Biophys Acta 2015 May;1852(5):893-904.

Pesce JT, Ramalingam TR, Mentink-Kane MM, Wilson MS, El Kasmi KC, Smith AM, Thompson RW, Cheever AW, Murray PJ, Wynn TA. Arginase-1-expressing macrophages suppress Th2 cytokine-driven inflammation and fibrosis. PLoS Pathog. 2009 Apr;5(4):e1000371.

Pesce JT, Ramalingam TR, Wilson MS, Mentink-Kane MM, Thompson RW, Cheever AW, Urban JF, Jr., Wynn TA. Retnla (relmalpha/fizz1) suppresses helminth-induced Th2-type immunity. PLoS Pathog. 2009 Apr;5(4):e1000393.

Peterson JM, Feeback KD, Baas JH, Pizza FX. Tumor necrosis factor-alpha promotes the accumulation of neutrophils and macrophages in skeletal muscle. $J$ Appl Physiol (1985). 2006 Nov;101(5):1394-9.

Pette D. Historical Perspectives: plasticity of mammalian skeletal muscle. J Appl Physiol (1985). 2001 Mar;90(3):1119-24. 
Powers SK, Howley ET. Fisiologia do exercício: teoria e aplicação ao condicionamento físico e ao desempenho. Barueri: Manole; 2009.

Proske U, Allen TJ. Damage to skeletal muscle from eccentric exercise. Exerc Sport Sci Rev. 2005 Apr;33(2):98-104.

Proske U, Gregory JE, Morgan DL, Percival P, Weerakkody NS, Canny BJ. Force matching errors following eccentric exercise. Hum Mov Sci. 2004 Oct;23(3-4):365-78.

Proske U, Morgan DL. Muscle damage from eccentric exercise: mechanism, mechanical signs, adaptation and clinical applications. J Physiol. 2001 Dec 1;537(Pt 2):333-45.

Purslow PP. Strain-induced reorientation of an intramuscular connective tissue network: implications for passive muscle elasticity. J Biomech. 1989;22(1):21-31.

Quintana HT, Bortolin JA, da Silva NT, Ribeiro FA, Liberti EA, Ribeiro DA, de Oliveira F. Temporal study following burn injury in young rats is associated with skeletal muscle atrophy, inflammation and altered myogenic regulatory factors. Inflamm Res. 2015 Jan;64(1):53-62.

Rao P, Hayden MS, Long M, Scott ML, West AP, Zhang D, Oeckinghaus A, Lynch C, Hoffmann A, Baltimore D, Ghosh S. IkappaBbeta acts to inhibit and activate gene expression during the inflammatory response. Nature. 2010 Aug 26;466(7310):11159.

Reich TE, Lindstedt SL, LaStayo PC, Pierotti DJ. Is the spring quality of muscle plastic? Am J Physiol Regul Integr Comp Physiol. 2000 Jun;278(6):R1661-6.

Rigamonti E, Touvier T, Clementi E, Manfredi AA, Brunelli S, Rovere-Querini P. Requirement of inducible nitric oxide synthase for skeletal muscle regeneration after acute damage. J Immunol. 2013 Feb 15;190(4):1767-77.

Roig M, Maclntyre DL, Eng JJ, Narici MV, Maganaris CN, Reid WD. Preservation of eccentric strength in older adults: Evidence, mechanisms and implications for training and rehabilitation. Exp Gerontol. 2010 Jun;45(6):400-9.

Sacco P, Jones DA. The protective effect of damaging eccentric exercise against repeated bouts of exercise in the mouse tibialis anterior muscle. Exp Physiol. 1992 Sep;77(5):757-60.

Saclier M, Cuvellier S, Magnan M, Mounier R, Chazaud B. Monocyte/macrophage interactions with myogenic precursor cells during skeletal muscle regeneration. FEBS J. 2013 Sep;280(17):4118-30.

Saclier M, Yacoub-Youssef H, Mackey AL, Arnold L, Ardjoune H, Magnan M, Sailhan F, Chelly J, Pavlath GK, Mounier R, Kjaer M, Chazaud B. Differentially Activated Macrophages Orchestrate Myogenic Precursor Cell Fate During Human Skeletal Muscle Regeneration. Stem Cells. 2013 Feb;31(2):384-96. 
Sakurai T, Kashimura O, Kano Y, Ohno H, Ji LL, Izawa T, Best TM. Role of nitric oxide in muscle regeneration following eccentric muscle contractions in rat skeletal muscle. Journal of Physiological Sciences. 2013 Jul;63(4):263-70.

Sam M, Shah S, Friden J, Milner DJ, Capetanaki Y, Lieber RL. Desmin knockout muscles generate lower stress and are less vulnerable to injury compared with wildtype muscles. Am J Physiol-Cell Ph. 2000 Oct;279(4):C1116-C22.

Sawant DV, Sehra S, Nguyen ET, Jadhav R, Englert K, Shinnakasu R, Hangoc G, Broxmeyer HE, Nakayama T, Perumal NB, Kaplan MH, Dent AL. Bcl6 controls the Th2 inflammatory activity of regulatory $T$ cells by repressing Gata3 function. J Immunol. 2012 Nov 15;189(10):4759-69.

Schiaffino S, Partridge T. Skeletal muscle repair and regeneration. New York: Springer; 2008.

Shen YC, Yen JC, Liou KT. Ameliorative effects of caffeic acid phenethyl ester on an eccentric exercise-induced skeletal muscle injury by down-regulating NF-kappab mediated inflammation. Pharmacology. 2013;91(3-4):219-28.

Shireman PK, Contreras-Shannon V, Ochoa O, Karia BP, Michalek JE, McManus LM. MCP-1 deficiency causes altered inflammation with impaired skeletal muscle regeneration. J Leukoc Biol. 2007 Mar;81(3):775-85.

Silva LA, Bom KF, Tromm CB, Rosa GL, Mariano I, Pozzi BG, Tuon T, Stresck EL, Souza CT, Pinho RA. Effect of eccentric training on mitochondrial function and oxidative stress in the skeletal muscle of rats. Braz J Med Biol Res. 2013 Jan;46(1):14-20.

Silva LA, Tromm CB, Da Rosa G, Bom K, Luciano TF, Tuon T, De Souza CT, Pinho RA. Creatine supplementation does not decrease oxidative stress and inflammation in skeletal muscle after eccentric exercise. J Sports Sci. 2013;31(11):1164-76.

Silva LH, Silva MT, Gutierrez RM, Conte TC, Toledo CA, Aoki MS, Liebano RE, Miyabara EH. GaAs 904-nm laser irradiation improves myofiber mass recovery during regeneration of skeletal muscle previously damaged by crotoxin. Laser Med Sci. 2012 Sep;27(5):993-1000.

Silva, RB. Respostas musculares à realização de ações excêntricas em diferentes velocidades e sua influência no efeito da carga repetida. Teses e Dissertações da USP. 2007 Ago;54.

Sindrilaru A, Peters T, Wieschalka S, Baican C, Baican A, Peter H, Hainzl A, Schatz S, Qi Y, Schlecht A, Weiss JM, Wlaschek M, Sunderkotter C, Scharffetter-Kochanek K. An unrestrained proinflammatory M1 macrophage population induced by iron impairs wound healing in humans and mice. J Clin Invest. 2011 Mar;121(3):985-97.

Smith LL, McKune AJ, Semple SJ, Sibanda E, Steel H, Anderson R. Changes in serum cytokines after repeated bouts of downhill running. Appl Physiol Nutr Metab 2007 Apr;32(2):233-40. 
Stutz AM, Pickart LA, Trifilieff A, Baumruker T, Prieschl-Strassmayr E, Woisetschlager $M$. The Th2 cell cytokines IL-4 and IL-13 regulate found in inflammatory zone 1/resistin-like molecule alpha gene expression by a STAT6 and CCAAT/enhancer-binding protein-dependent mechanism. J Immunol 2003 Feb; 170(4):1789-96.

Tajsharghi $\mathrm{H}$. Thick and thin filament gene mutations in striated muscle diseases. Int J Mol Sci. 2008 Jul;9(7):1259-75.

Tiidus PM. Skeletal muscle damage and repair. Leeds: Human Kinetics; 2008.

Touchberry CD, Gupte AA, Bomhoff GL, Graham ZA, Geiger PC, Gallagher PM. Acute heat stress prior to downhill running may enhance skeletal muscle remodeling. Cell Stress Chaperon. 2012 Nov;17(6):693-705.

Valero MC, Huntsman HD, Liu JM, Zou K, Boppart MD. Eccentric Exercise Facilitates Mesenchymal Stem Cell Appearance in Skeletal Muscle. Plos One. 2012 Jan $11 ; 7(1)$.

Vijayan K, Thompson JL, Norenberg KM, Fitts RH, Riley DA. Fiber-type susceptibility to eccentric contraction-induced damage of hindlimb-unloaded rat $A L$ muscles. J Appl Physiol (1985). 2001 Mar;90(3):770-6.

Villalta SA, Deng B, Rinaldi C, Wehling-Henricks M, Tidball JG. IFN-gamma promotes muscle damage in the mdx mouse model of Duchenne muscular dystrophy by suppressing M2 macrophage activation and inhibiting muscle cell proliferation. J Immunol. 2011 Nov 15;187(10):5419-28.

Vissing K, Bayer ML, Overgaard K, Schjerling P, Raastad T. Heat shock protein translocation and expression response is attenuated in response to repeated eccentric exercise. Acta Physiol. 2009 Jul;196(3):283-93.

Vissing $\mathrm{K}$, Overgaard $\mathrm{K}$, Nedergaard A, Fredsted A, Schjerling P. Effects of concentric and repeated eccentric exercise on muscle damage and calpaincalpastatin gene expression in human skeletal muscle. Eur J Appl Physiol. 2008 Jun;103(3):323-32.

Walmsley B, Hodgson JA, Burke RE. Forces produced by medial gastrocnemius and soleus muscles during locomotion in freely moving cats. J Neurophysiol. 1978 Sep;41(5):1203-16.

Walsh LD, Hesse CW, Morgan DL, Proske U. Human forearm position sense after fatigue of elbow flexor muscles. J Physiol. 2004 Jul 15;558(Pt 2):705-15.

Warren GL, Hermann KM, Ingalls CP, Masselli MR, Armstrong RB. Decreased EMG median frequency during a second bout of eccentric contractions. Med Sci Sports Exerc. 2000 Apr;32(4):820-9. 
Warren GL, Ingalls CP, Lowe DA, Armstrong RB. Excitation-contraction uncoupling: major role in contraction-induced muscle injury. Exerc Sport Sci Rev. 2001 Apr;29(2):82-7.

Wehling-Henricks M, Jordan MC, Gotoh T, Grody WW, Roos KP, Tidball JG. Arginine metabolism by macrophages promotes cardiac and muscle fibrosis in mdx muscular dystrophy. Plos One. 2010;5(5):e10763.

Welch JS, Escoubet-Lozach L, Sykes DB, Liddiard K, Greaves DR, Glass CK. TH2 cytokines and allergic challenge induce Ym1 expression in macrophages by a STAT6-dependent mechanism. J Biol Chem. 2002 Nov 8;277(45):42821-9.

Wynn TA. Fibrotic disease and the $\mathrm{T}(\mathrm{H}) 1 / \mathrm{T}(\mathrm{H}) 2$ paradigm. Nat Rev Immunol. 2004 Aug;4(8):583-94.

Yanagisawa O, Kurihara T, Okumura K, Fukubayashi T. Effects of strenuous exercise with eccentric muscle contraction: physiological and functional aspects of human skeletal muscle. Magn Reson Med Sci. 2010;9(4):179-86.

Yin X, Wang Q, Chen T, Niu J, Ban R, Liu J, Mao Y, Pu C. CD4+ cells, macrophages, MHC-I and C5b-9 involve the pathogenesis of dysferlinopathy. Int $\mathrm{J}$ Clin Exp Pathol. 2015;8(3):3069-75.

Yusuf F, Brand-Saberi B. Myogenesis and muscle regeneration. Histochem Cell Biol. 2012 Aug;138(2):187-99.

Zanou N, Gailly P. Skeletal muscle hypertrophy and regeneration: interplay between the myogenic regulatory factors (MRFs) and insulin-like growth factors (IGFs) pathways. Cell Mol Life Sci. 2013 Nov;70(21):4117-30.

Zhang C, Li Y, Wu Y, Wang L, Wang X, Du J. Interleukin-6/signal transducer and activator of transcription 3 (STAT3) pathway is essential for macrophage infiltration and myoblast proliferation during muscle regeneration. J Biol Chem. 2013 Jan 18;288(3):1489-99.

Zhong B, Yang X, Sun, Q, Liu L, Lan, X, Tian J, He Q, Hou W, Liu H, Jiang C, Gao $\mathrm{N}$, Lu S. Pdcd4 modulates markers of macrophage alternative activation and airway remodeling in antigen-induced pulmonary inflammation. J Leukoc Biol 2014 Dec;96(6):1065-75. 